\title{
Trends in Sea Otter Population Abundance in Western Prince William Sound, Alaska: Progress Toward Recovery Following the 1989 Exxon Valdez Oil Spill
}

Scientific Investigations Report 2011-5213 



\section{Trends in Sea Otter Population Abundance in Western Prince William Sound, Alaska: Progress Toward Recovery Following the 1989 Exxon Valdez Oil Spill}

By J.L. Bodkin, B.E. Ballachey, and G.G. Esslinger

Scientific Investigations Report 2011-5213 


\title{
U.S. Department of the Interior \\ KEN SALAZAR, Secretary \\ U.S. Geological Survey \\ Marcia K. McNutt, Director
}

\author{
U.S. Geological Survey, Reston, Virginia: 2011
}

For more information on the USGS - the Federal source for science about the Earth, its natural and living resources, natural hazards, and the environment, visit http://www.usgs.gov or call 1-888-ASK-USGS.

For an overview of USGS information products, including maps, imagery, and publications, visit http://www.usgs.gov/pubprod

To order this and other USGS information products, visit http://store.usgs.gov

Any use of trade, product, or firm names is for descriptive purposes only and does not imply endorsement by the U.S. Government.

Although this report is in the public domain, permission must be secured from the individual copyright owners to reproduce any copyrighted materials contained within this report.

Suggested citation:

Bodkin, J.L., Ballachey, B.E., and Esslinger, G.G., 2011, Trends in sea otter population abundance in western Prince William Sound, Alaska: Progress toward recovery following the 1989 Exxon Valdez oil spill: U.S. Geological Survey Scientific Investigations Report 2011-5213, 14 p. 


\section{Contents}

Abstract
Introduction.
Description of Study Area
Methods.
Results
Discussion
Conclusions

\section{Figures}

Figure 1. Map showing Prince William Sound, Alaska ................................ 2

Figure 2. Map showing northern Knight Island (heavily oiled) and Montague Island (unoiled) intensive study areas in western Prince William Sound, Alaska $\ldots . . . . \quad 3$

Figure 3. Graph showing sea otter population trend in western Prince William Sound, Alaska, 1993-2009 ..........................................................

Figure 4. Maps showing distribution and relative abundance of sea otters observed along transects surveyed in western Prince William Sound, Alaska, 2008-09 .......... 6

Figure 5. Graph showing sea otter population trend at Montague Island, Prince William Sound, 1993-2009

Figure 6. Maps showing sea otter distribution and relative abundance at Montague and northern Knight Islands, Prince William Sound, Alaska, 2008-09 ................ 9

Figure 7. Graph showing sea otter population trends at the northern Knight Island, Prince William Sound study area, 1993-2009 ..................................... 11

\section{Tables}

Table 1. Estimates of sea otter population size from western Prince William Sound, Alaska, 1993-2009, based on aerial surveys methods of Bodkin and Udevitz (1994)

Table 2. Estimates of sea otter population size from Montague Island, Prince William Sound, Alaska, 1993-2009, based on aerial survey methods of Bodkin and Udevitz (1999)

Table 3. Estimates of sea otter population size from northern Knight Island, Prince William Sound, 1993-2009, based on aerial survey methods of Bodkin and Udevitz (1999) 


\section{Conversion Factors and Datum}

Conversion Factors

\begin{tabular}{lll}
\hline \multicolumn{1}{c}{ Multiply } & By & \multicolumn{1}{c}{ To obtain } \\
\hline meter $(\mathrm{m})$ & 3.281 & foot $(\mathrm{ft})$ \\
kilometer $(\mathrm{km})$ & 0.6214 & mile $(\mathrm{mi})$ \\
square kilometer $\left(\mathrm{km}^{2}\right)$ & 0.3861 & square mile $\left(\mathrm{mi}^{2}\right)$ \\
\hline
\end{tabular}

Datum

Horizontal coordinate information is referenced to North American Datum of 1983 (NAD 83). 


\title{
Trends in Sea Otter Population Abundance in Western Prince William Sound, Alaska: Progress Toward Recovery Following the 1989 Exxon Valdez Oil Spill
}

\author{
By J.L. Bodkin, B.E. Ballachey, and G.G. Esslinger
}

\begin{abstract}
Sea otters in western Prince William Sound (WPWS) and elsewhere in the Gulf of Alaska suffered widespread mortality as a result of oiling following the 1989 T/V Exxon Valdez oil spill. Following the spill, extensive efforts have been directed toward identifying and understanding long-term consequences of the spill and the process of recovery. We conducted annual aerial surveys of sea otter abundance from 1993 to 2009 (except for 2001 and 2006) in WPWS. We observed an increasing trend in population abundance at the scale of WPWS through 2000 at an average annual rate of 4 percent: however, at northern Knight Island where oiling was heaviest and sea otter mortality highest, no increase in abundance was evident by 2000 . We continued to see significant increase in abundance at the scale of WPWS between 2001 and 2009, with an average annual rate of increase from 1993 to 2009 of 2.6 percent. We estimated the 2009 population size of WPWS to be 3,958 animals (standard error $=653$ ), nearly 2,000 animals more than the first post-spill estimate in 1993. Surveys since 2003 also have identified a significant increasing trend at the heavily oiled site in northern Knight Island, averaging about 25 percent annually and resulting in a 2009 estimated population size of 116 animals (standard error =19). Although the 2009 estimate for northern Knight Island remains about 30 percent less than the pre-spill estimate of 165 animals, we interpret this trend as strong evidence of a trajectory toward recovery of spill-affected sea otter populations in WPWS.
\end{abstract}

\section{Introduction}

Sea otter populations in western Prince William Sound (WPWS) were injured as a result of the 1989 Exxon Valdez oil spill (EVOS) (Ballachey and others, 1994). Effects included both acute mortality, resulting from contact with spilled oil in the days and months following the spill, and chronic effects, resulting from sub-lethal initial exposure or protracted exposure to lingering oil, or indirect effects, for example, from reduced prey populations or other ecosystem disturbances (Peterson, 2000; Peterson and others, 2003). Estimates of sea otter mortality due to acute effects of the oil spill in WPWS ranged from 750 to 2,650 animals (Garrott and others, 1993; Garshelis, 1997). The disparity among acute mortality estimates largely reflects the lack of accurate pre-spill estimates of sea otter population size. Using population models, Udevitz and others (1996) predicted recovery of the WPWS sea otter population in 10-23 years, with maximum annual growth rates from 10 to 14 percent.

Since 1993, we have conducted aerial surveys of sea otter populations in WPWS annually to track the progress of sea otter recovery, except in 2001 and 2006. Results of surveys through 2000 demonstrated a significant increase of nearly 600 animals in WPWS, resulting in a statistically significant average annual increase of 4 percent per year since 1993 (Bodkin and others, 2002). This increase at the scale of WPWS was considered indicative of progress toward recovery, although the average annual rate of increase was about one-half the long-term growth rate experienced in Prince William Sound earlier in the 20th century (Bodkin and others, 2002). Additionally, Dean and others (2000) and Bodkin and others (2002) describe a situation at northern Knight Island in WPWS where there was no evidence of increase in sea otter abundance by 2000, more than a decade after the spill, and abundance was less than one-half of the population size prior to the spill.

Recovery of the Prince William Sound ecosystem from the EVOS may not be considered complete until individual animals are no longer exposed to lingering oil from the spill and populations reach pre-spill levels of abundance (Exxon Valdez Oil Spill Trustee Council, 2006). Aerial surveys of sea otters in WPWS provide a means to evaluate progress toward recovery goals. Here, we present abundance estimates derived from the aerial survey data and evaluate the trends in abundance evident in the time series of data from 1993 to 2009. 


\section{Description of Study Area}

Our survey efforts were focused on WPWS, the site of previous EVOS sea otter studies (Burn, 1994; Dean and others, 2000; Bodkin and others, 2002; Dean and others, 2002; Ballachey and others, 2003). We surveyed sea otter population sizes at two geographical scales: (1) a regional scale defined as WPWS and inclusive of all oiled areas and some adjacent lightly or non-oiled areas (fig. 1), and (2) an intensive scale within WPWS that included one heavily oiled site and one unoiled site. The intensive survey areas included an oiled area identified as the shorelines of the northern Knight Island archipelago and extended offshore to the $100 \mathrm{~m}$ depth contour (fig. 2). Oiling in 1989 was heaviest here, and sea otter populations generally are lower here than in other areas of Prince William Sound that were not oiled (Bodkin and Udevitz, 1999; Dean and others, 2002). The intensive survey area also included an unoiled area along the northwestern shore of Montague Island between Green and Montague Islands (fig. 2).

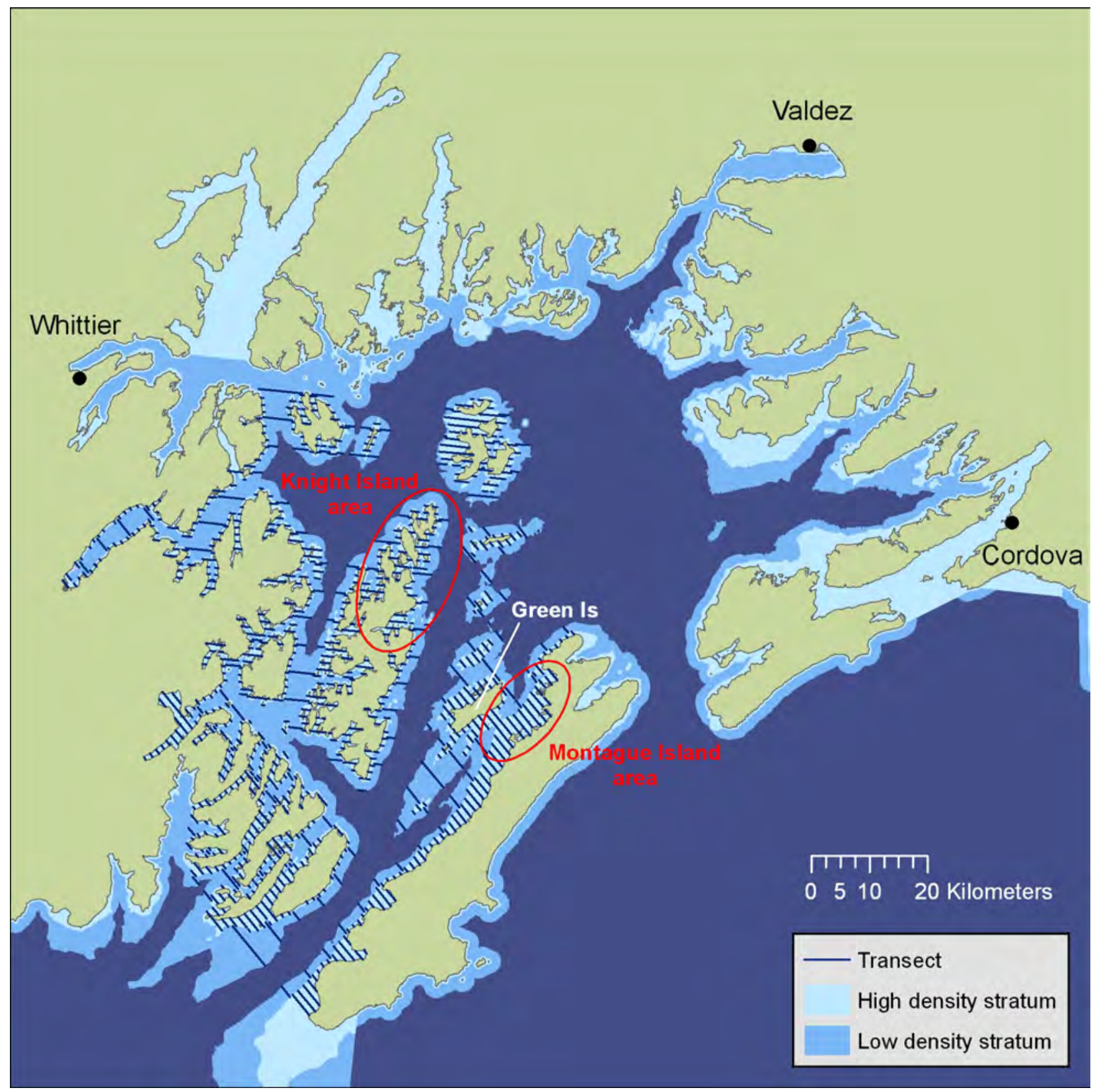

Figure 1. Prince William Sound, Alaska. Blue lines delineate the western Prince William Sound transects surveyed and collectively represent the survey area. Figure 2 shows the exact transects surveyed on Knight and Montague replicate surveys. The survey area includes all known oiled areas and includes adjacent areas that were lightly, or not oiled. High density stratum generally are defined by water depths less than $40 \mathrm{~m}$ and were sampled at a higher intensity than in the low density stratum that extends from the $40 \mathrm{~m}$ to the $200 \mathrm{~m}$ depth contour. 


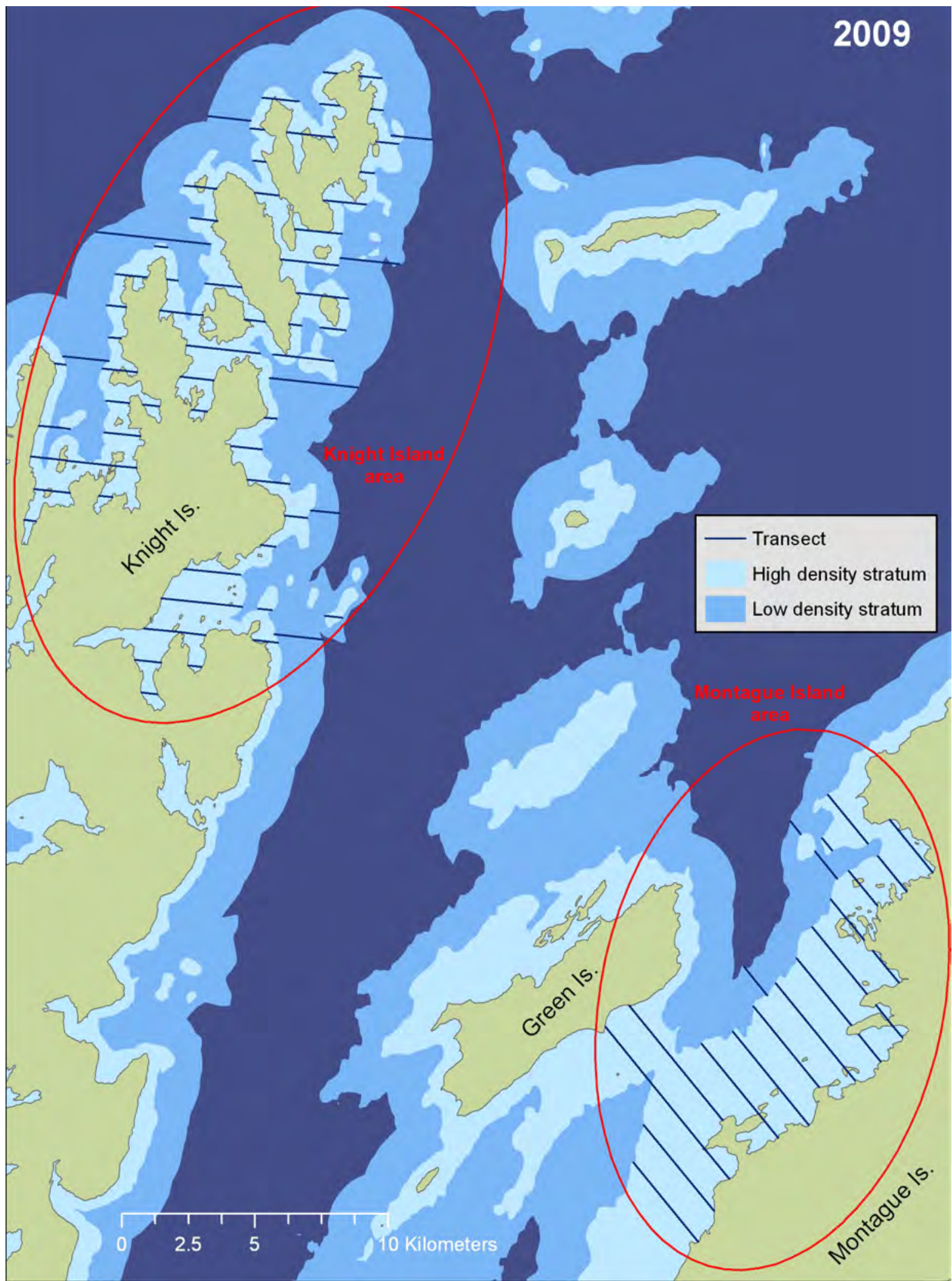

Figure 2. Northern Knight Island (heavily oiled) and Montague Island (unoiled) intensive study areas in western Prince William Sound, Alaska. Blue lines delineate transect lines surveyed and collectively represent the survey area. High density stratum are generally defined by water depths less than $40 \mathrm{~m}$ and were sampled at a higher intensity than in the low density stratum that extends from the $40-\mathrm{m}$ to the $100-\mathrm{m}$ depth contour. 


\section{Methods}

The aerial surveys of sea otters consist of two components: (1) strip transect counts and (2) intensive search units, which are fully described in Bodkin and Udevitz (1999). Sea otter habitat was sampled in two strata, high density and low density, distinguished by distance from shore and depth contour. Survey effort was allocated proportional to expected sea otter abundance by adjusting the systematic spacing of transects within each strata, with approximately 80 percent of the effort allocated to the high density stratum. Transects with a 400-m strip width on one side of a fixed-wing aircraft were surveyed by a single observer at an airspeed of $104 \mathrm{~km} / \mathrm{h}$ (29 m/s) at an altitude of $91 \mathrm{~m}$. The observer searched forward as far as conditions allowed and out laterally $400 \mathrm{~m}$, indicated by marks on the aircraft struts, and recorded each otter group size and location on a transect map. A group was defined as one or more otters spaced less than three otter lengths apart. Intensive search units (ISUs) were used to estimate the proportion of sea otters not detected on strip transect counts, and result in correction factors that are used to adjust strip counts for animals not detected. ISUs were conducted at intervals to provide a sample distribution throughout the survey period, and were initiated by the sighting of a group of sea otters. ISUs consisted of five concentric circles flown within the 400-m strip perpendicular to the group on the transect that initiated the ISU. Groups of sea otters initiating each ISU are not included in calculating detection.

To increase precision in estimates for the intensive oiled (northern Knight Island) and unoiled (Montague Island) areas, up to five replicate surveys were conducted using the same techniques described in Bodkin and Udevitz (1999). Replicate surveys were conducted during the same time period as the WPWS surveys (midsummer). Rates of change in population estimates over time were calculated by regressing the log $(N)$ of estimates over years.

\section{Results}

Western Prince William Sound: In 1993, we estimated a WPWS sea otter population size of 2,054 (SE = 698), and in 2009, we estimated a population size of 3,958 (SE =653). With the exception of 2001 and 2006, we estimated sea otter abundance in WPWS annually since 1993 (fig. 3 and table 1). From 1993 through 2000, a significant positive average annual growth rate of about 4 percent $\left(r^{2}=0.56, p=0.03\right)$ was evident. In 2002, it appeared as though there was an overall decrease in WPWS sea otter abundance, but subsequent estimates confirm the significant long-term trend toward an increasing sea otter population in WPWS. The average annual increase over the 17-year period (1993-2009) is about 2.6 percent $\left(r^{2}=0.43, p=0.02\right)$. The 2009 sea otter population estimate for WPWS $(3,958)$ represents an increase of 1,900 animals since we initiated aerial surveys in 1993 (2,054) following the EVOS (table 1). Distributions and relative abundance of sea otters detected during the WPWS surveys in 2008 and 2009 are provided in figure 4.

Montague Island (unoiled): We estimated a population size of 310 ( $\mathrm{SE}=62$ ) sea otters at our Montague Island survey area in 2009. At Montague Island, there has been a trend toward increasing sea otter abundance, with a nonsignificant average annual increase of about 1 percent (fig. 5 and table 2). The distribution of sea otters at Montague Island is presented in figure 6.

The Montague Island interannual variation has been high, particularly when considering years 2002, 2005, and 2009. This variation may be attributed to the relatively small area being surveyed and potential movement of animals to and from nearby Green Island, which borders the Montague intensive study area, as well as SW along Montague Island (fig. 6).

Knight Island (oiled): We estimated a population size of 116 ( $\mathrm{SE}=19)$ sea otters at the Knight Island survey area in 2009, 98 ( $\mathrm{SE}=24)$ in 2008, and $71(\mathrm{SE}=14)$ in 2007. Between 1993 and 2001, the sea otter population size at northern Knight Island remained generally constant, with an average abundance of 78 animals ( $\mathrm{SE}=2.1$ ) (fig. 7 and table 3), but apparently decreased abruptly between 2001 and 2002. In 2004, we began detecting an increasing trend at Knight Island that extends to 2009. Since 2003, the average annual increase has been about 25 percent, increasing from 26 animals in 2003 to 116 animals in 2009 (fig. 7, table 3). 


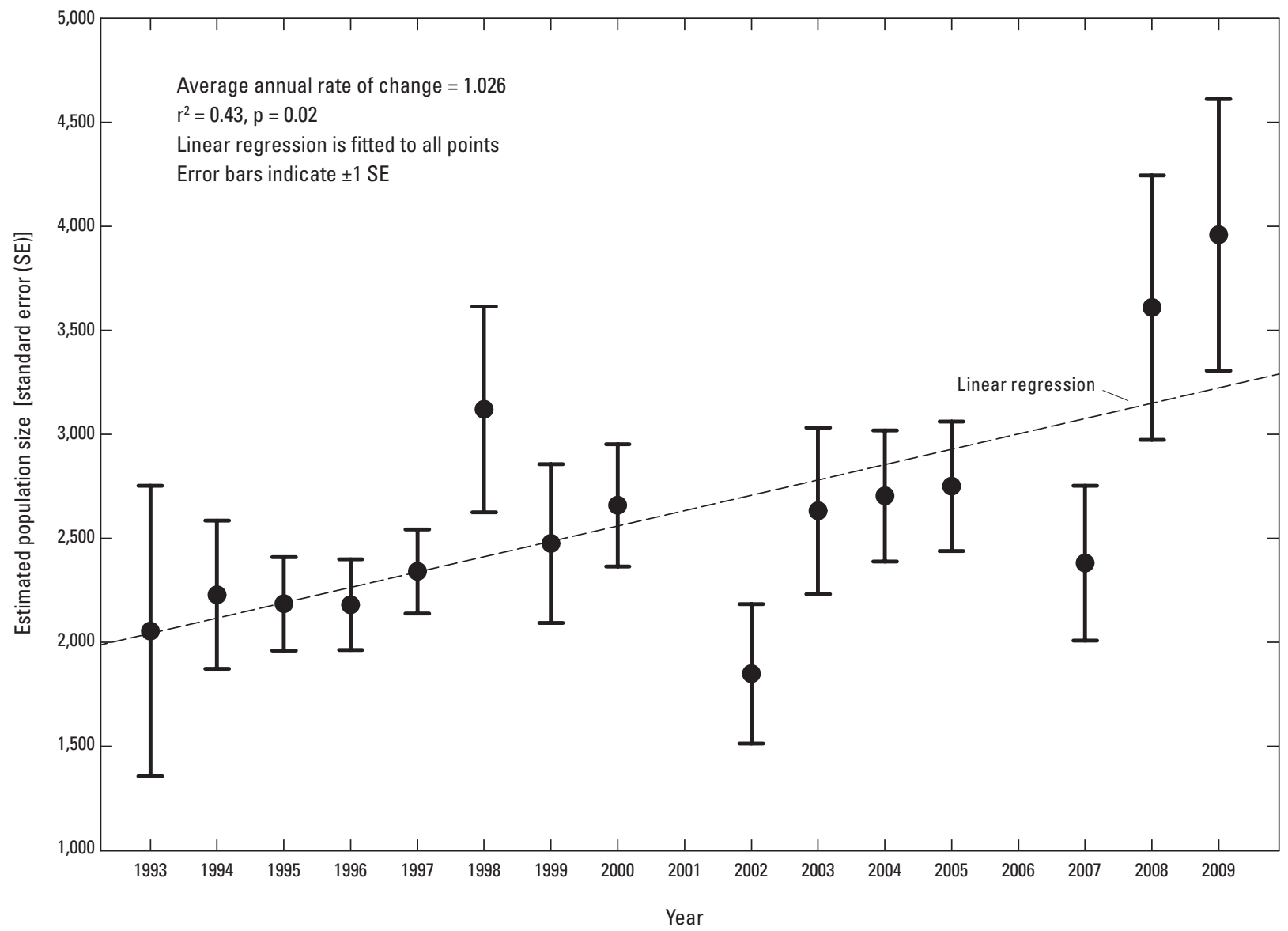

Figure 3. Sea otter population trend in western Prince William Sound, Alaska, 1993-2009.

Table 1. Estimates of sea otter population size from western Prince William Sound, Alaska, 1993-2009, based on aerial surveys methods of Bodkin and Udevitz (1994).

[-, no estimate]

\begin{tabular}{ccc}
\hline Year & $\begin{array}{c}\text { Estimated } \\
\text { population size } \\
\text { (number of sea otters) }\end{array}$ & $\begin{array}{c}\text { Standard } \\
\text { error }\end{array}$ \\
\hline 1993 & 2,054 & 698 \\
1994 & 2,228 & 356 \\
1995 & 2,185 & 225 \\
1996 & 2,180 & 218 \\
1997 & 2,341 & 202 \\
1998 & 3,119 & 494 \\
1999 & 2,475 & 381 \\
2000 & 2,658 & 294 \\
2001 & - & - \\
2002 & 1,849 & 334 \\
2003 & 2,631 & 400 \\
2004 & 2,704 & 315 \\
2005 & 2,751 & 311 \\
2006 & - & - \\
2007 & 2,380 & 372 \\
2008 & 3,609 & 635 \\
2009 & 3,958 & 653 \\
\hline
\end{tabular}




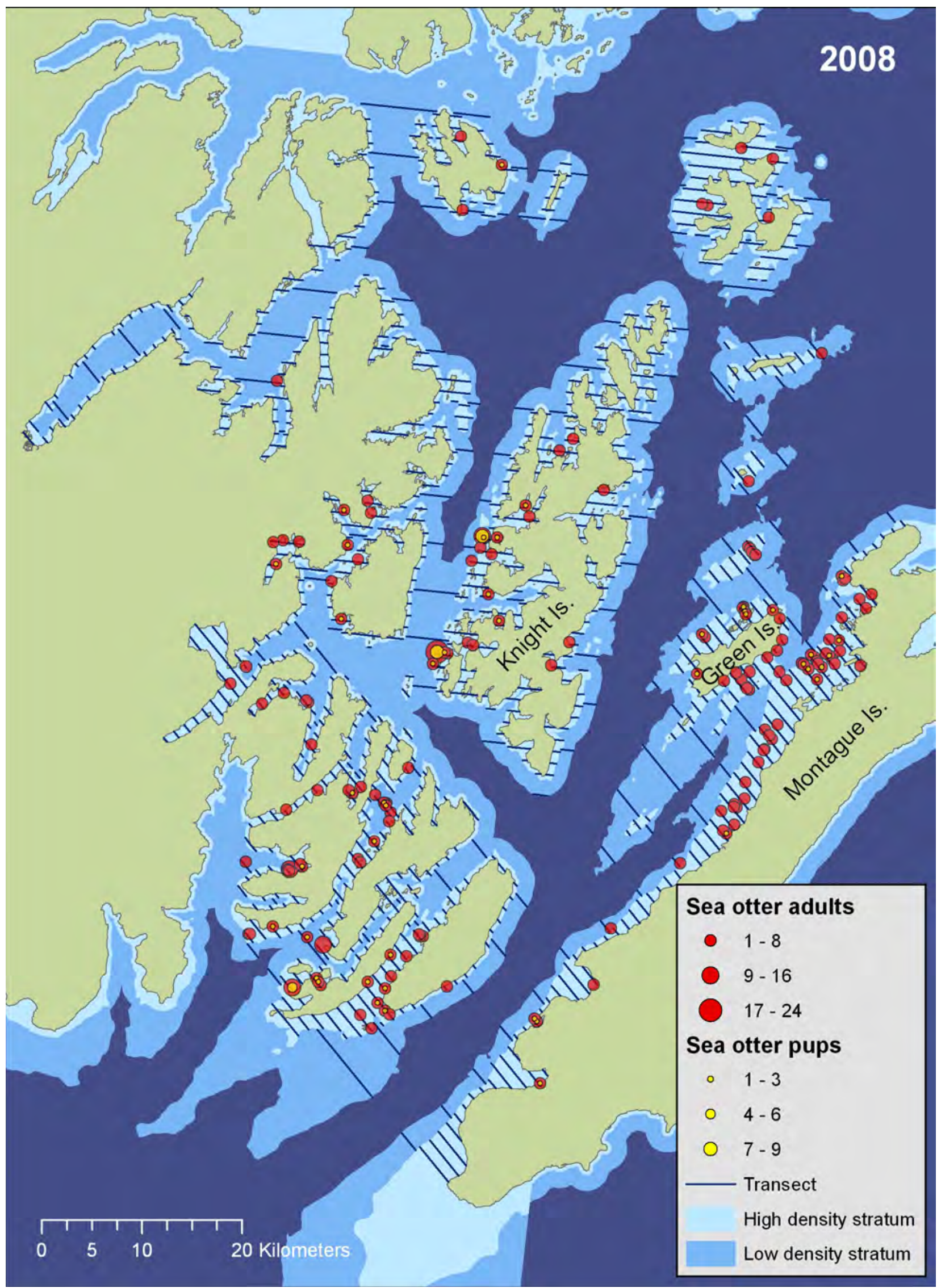

Figure 4. Distribution and relative abundance of sea otters observed along transects surveyed in western Prince William Sound, Alaska, 2008-09. 


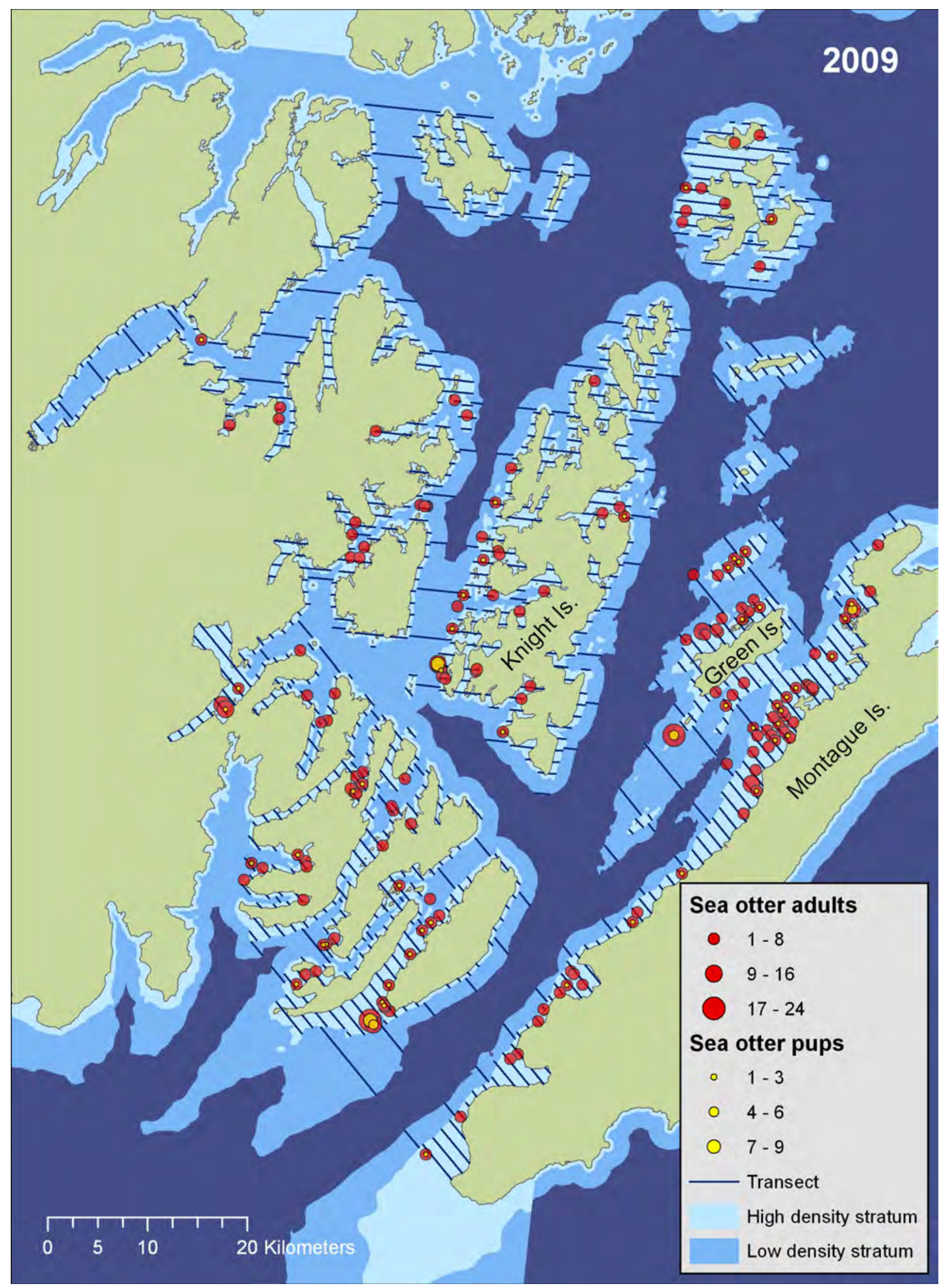

Figure 4.-Continued 


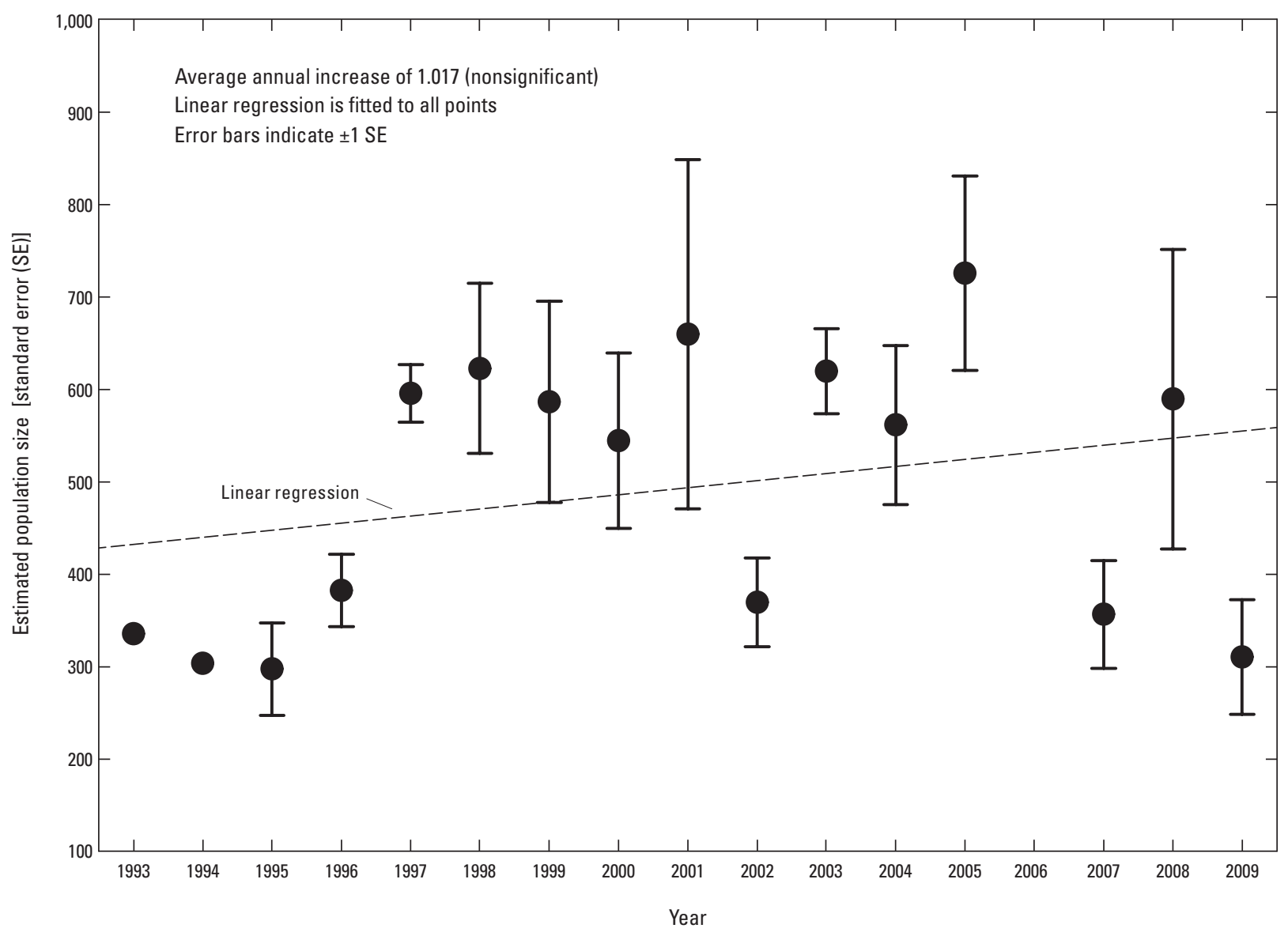

Figure 5. Sea otter population trend at Montague Island, Prince William Sound, 1993-2009.

Table 2. Estimates of sea otter population size from Montague Island, Prince William Sound, Alaska, 1993-2009, based on aerial survey methods of Bodkin and Udevitz (1999).

$[-$, no estimate $]$

\begin{tabular}{ccc}
\hline Year & $\begin{array}{c}\text { Estimated } \\
\text { population size } \\
\text { (number of sea otters) }\end{array}$ & $\begin{array}{c}\text { Standard } \\
\text { error }\end{array}$ \\
\hline 1993 & 335 & - \\
1994 & 303 & - \\
1995 & 297 & 50 \\
1996 & 382 & 39 \\
1997 & 595 & 31 \\
1998 & 622 & 92 \\
1999 & 586 & 109 \\
2000 & 544 & 95 \\
2001 & 659 & 189 \\
2002 & 369 & 48 \\
2003 & 619 & 46 \\
2004 & 561 & 86 \\
2005 & 725 & 105 \\
2006 & - & - \\
2007 & 356 & 58 \\
2008 & 589 & 162 \\
2009 & 310 & 62 \\
\hline
\end{tabular}




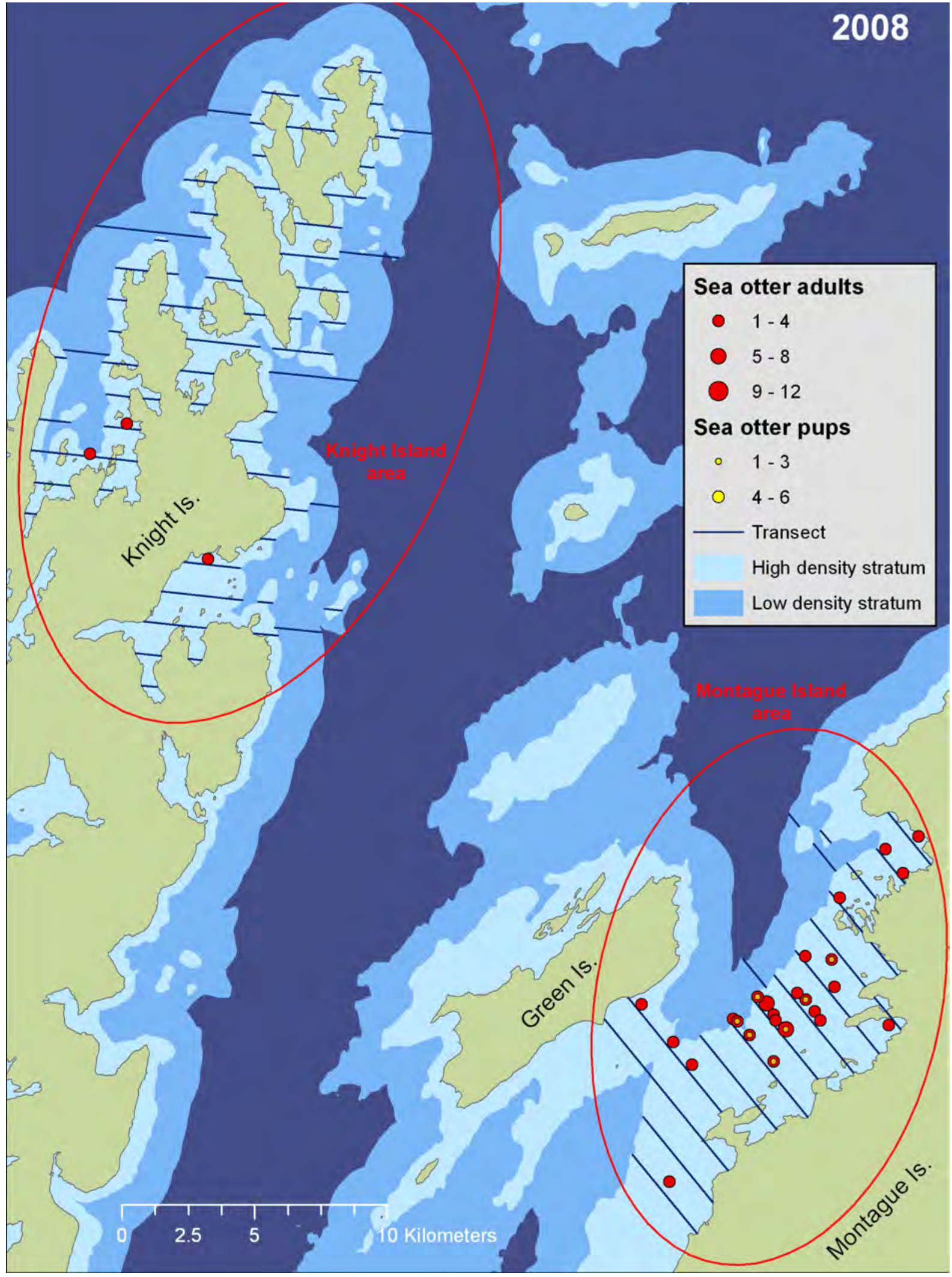

Figure 6. Sea otter distribution and relative abundance at Montague and northern Knight Islands, Prince William Sound, Alaska, 2008-09. Data from one replicate survey only. 


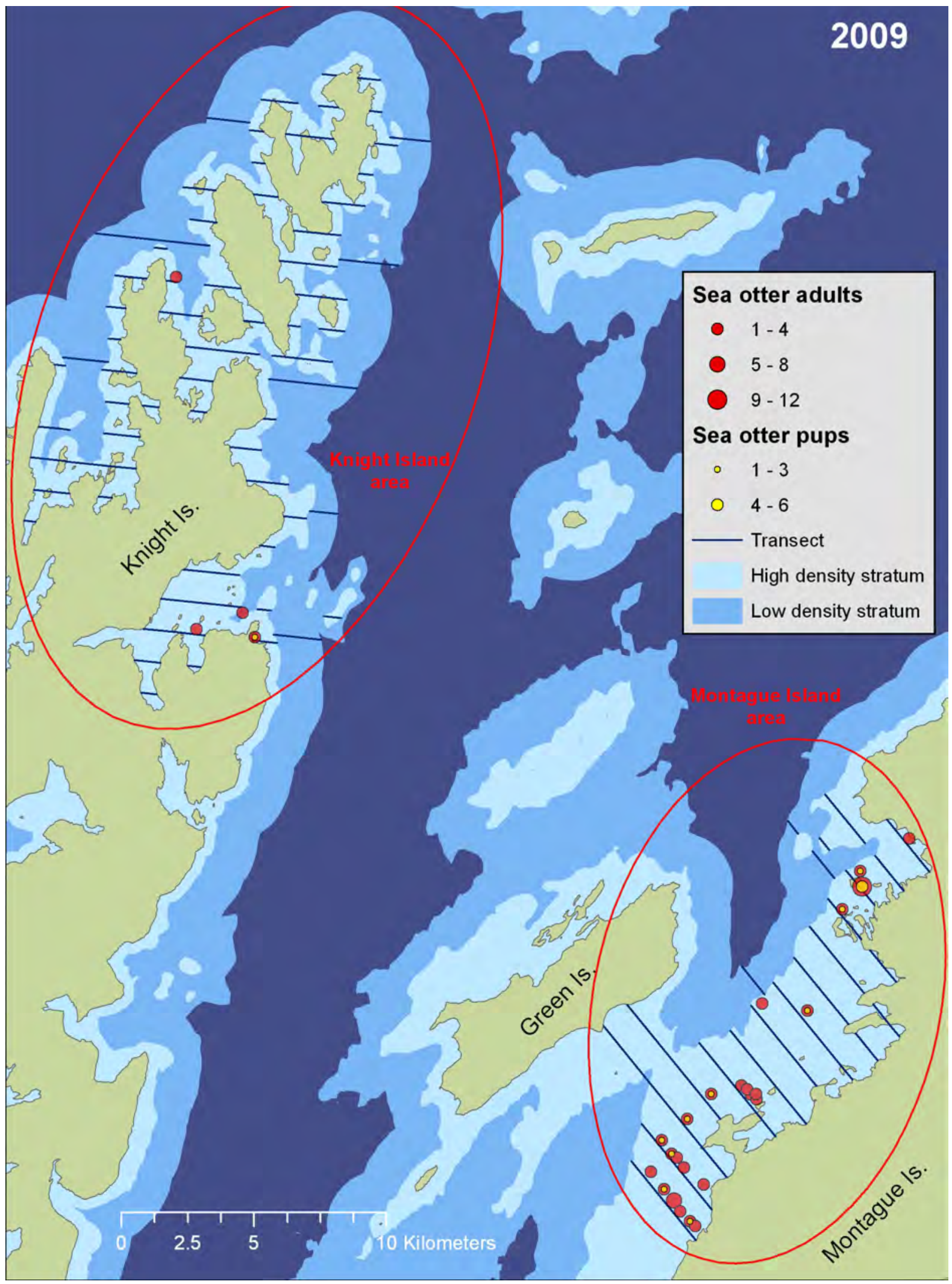

Figure 6.-Continued 


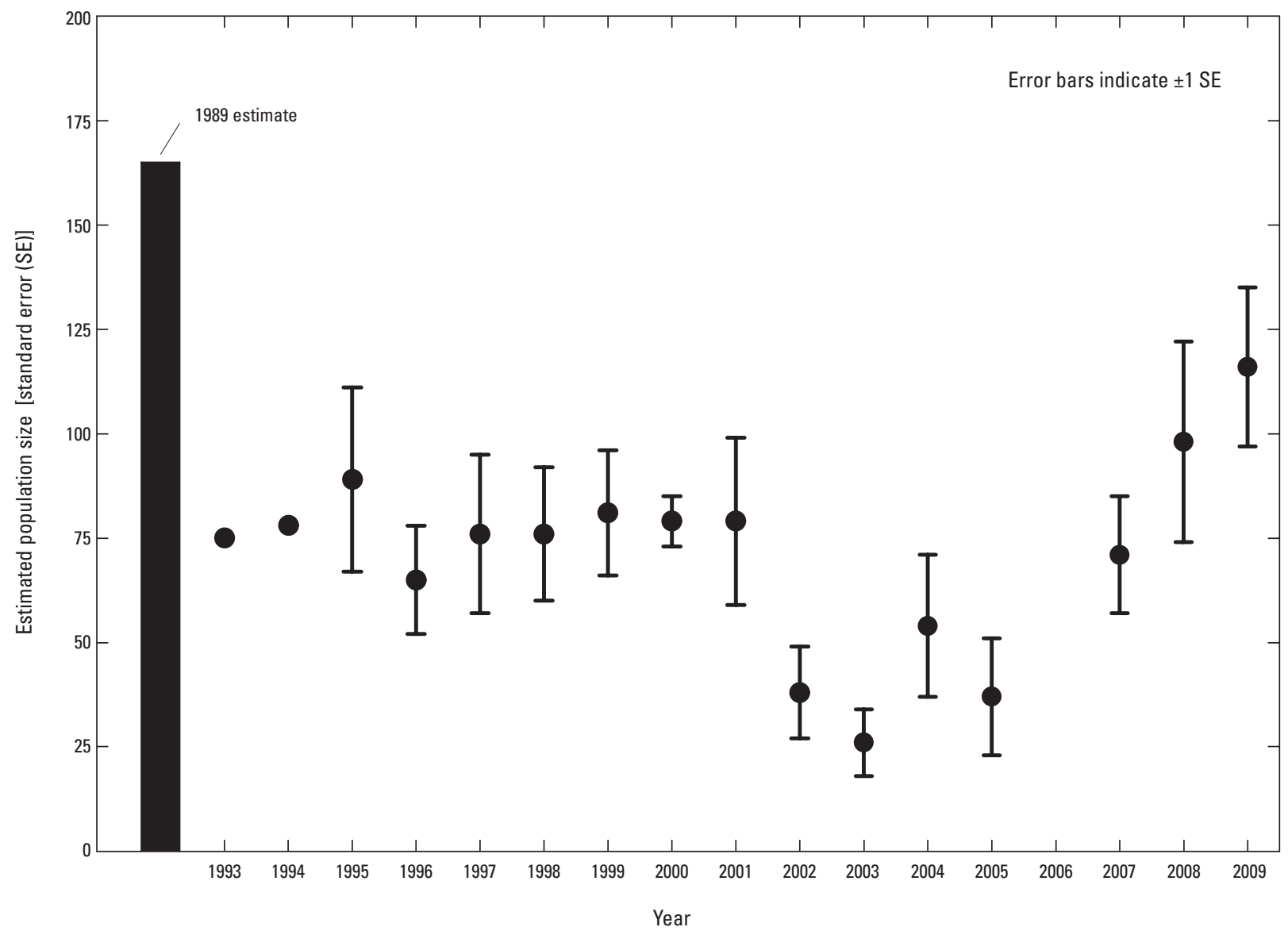

Figure 7. Sea otter population trends at the northern Knight Island, Prince William Sound study area, 1993-2009. The 1989 estimate of pre-spill abundance is from Dean and others (2000).

Table 3. Estimates of sea otter population size from northern Knight Island, Prince William Sound, 1993-2009, based on aerial survey methods of Bodkin and Udevitz (1999).

[-, no estimate]

\begin{tabular}{ccc}
\hline Year & $\begin{array}{c}\text { Estimated } \\
\text { population size } \\
\text { (number of sea otters) }\end{array}$ & $\begin{array}{c}\text { Standard } \\
\text { error }\end{array}$ \\
\hline 1993 & 75 & - \\
1994 & 78 & - \\
1995 & 89 & 22 \\
1996 & 65 & 13 \\
1997 & 76 & 19 \\
1998 & 76 & 16 \\
1999 & 81 & 15 \\
2000 & 79 & 6 \\
2001 & 79 & 20 \\
2002 & 38 & 11 \\
2003 & 26 & 8 \\
2004 & 54 & 17 \\
2005 & 37 & 14 \\
2006 & - & - \\
2007 & 71 & 14 \\
2008 & 98 & 24 \\
2009 & 116 & 19 \\
\hline
\end{tabular}




\section{Discussion}

The general pattern of sea otter abundance in WPWS is significantly positive and consistent over the 17 -year period from 1993 to 2009. The two most recent estimates represent an increase of about 1,500-2,000 animals since 1993, and we interpret that as evidence of recovery from the spill at the scale of WPWS. Acute spill related mortality estimates for WPWS range from 750 (Garshelis, 1997) to about 2,650 animals (Garrott and others, 1993). If the present estimates reflect recovery from the EVOS, it would appear that the higher initial mortality estimate provided by Garrott and others (1993) may be the more accurate.

The distribution of sea otters across the WPWS survey area has remained relatively stable among years. The general distribution represented in figure 4 for 2008 and 2009 is similar among other survey years. This likely reflects the small home ranges resulting from high fidelity to specific resting and foraging areas exhibited by sea otters. Although capable of movements on the order of $100 \mathrm{~km}$, the annual home ranges of adult sea otters generally include less than $20 \mathrm{~km}$ of shore and range from a few, to a few tens of square kilometers (Riedman and Estes, 1990; Estes and others, 2008). These limited movements may in part be responsible for the protracted recovery period exhibited by sea otters following the EVOS. If sea otters exhibited greater movements, then perhaps recovery would have been facilitated more rapidly through immigration of individuals from outside the spill-affected area. Alternatively, if the presence of lingering oil in nearshore areas (Petersen and others, 2003; Short and others, 2004, 2006) either dissuades potential immigrants, or results in reduced survival (Monson and others, 2000) in the spill area, then perhaps the process of recovery from events, such as this oil spill, may be independent of animal movements.

The trend toward increasing abundance at Montague Island is consistent with the increasing trend observed in the larger spill area of WPWS, although at a reduced rate. The trend also is consistent in representing a population that was not affected by the 1989 oil spill, and thus not expected to attain the magnitude of increase observed in the neighboring spill area where mortality estimates were high and recovery was expected.

The estimates of population size at Montague Island exhibit high variation among years (table 2), which may be explained by several factors. First, the survey area is relatively small (about $100 \mathrm{~km}^{2}$ ), allowing movements of sea otters into and out of the survey area over short time intervals to affect estimates. Second, there is relatively high connectivity through shallow habitat, north to Green Island and southwest along Montague Island (ig. 2) that would facilitate movements at the local scale. Third, the Montague Island study area supports a summer commercial fishery for hatchery reared salmon that in some years coincides with our survey. This latter effect was particularly evident in 2009 when, for the first time since 1993, a gill net fishery occurred, as compared to prior years when the fishery was exclusively conducted by purse seiners. The gill net fishery consisted of dozens of vessels with nets set for extended periods in nearshore waters over a large area, whereas the seine fishery was more centrally located and conducted by fewer vessels with less interaction with sea otters. As a result, it appears that sea otters shifted their distribution southwest of our intensive survey area in 2009 (figs. 4 and $\underline{6}$ ). The relative contribution of movements and disturbance from fisheries to high interannual variation in abundance estimates at Montague Island is unknown.

Based on the number of sea otter carcasses recovered and those that were captured alive for rehabilitation in 1989, Dean and others (2000) estimated a population size in our Knight Island intensive survey area of 165 animals at the time of the spill. The 1993-2001 mean of 78 animals represents a decrease of 53 percent from the pre-spill estimate, and the 2003 estimate of 26 animals represents an 84 percent decrease from pre-spill and a 64 percent decrease from the 1993-2001 mean of 78 animals. After 2003, the sea otter population at Knight Island appeared to increase in abundance, with the 2009 estimate of 116 animals representing an average annual increase of about 25 percent since $2003\left(r^{2}=0.87, p=0.007\right)$. However, the 2009 estimate remains 30 percent less than the pre-spill estimate (fig. 7).

We interpret the significant increasing trend in sea otter abundance at northern Knight Island to indicate progress toward recovery from the 1989 EVOS. This area of intensive study was selected in the years following the spill in recognition of the severity of oiling and sea otter mortality that approached 90 percent in some areas (Bodkin and Udevitz, 1994). An assumption inherent in this selection was that when recovery was evident in those areas most severely affected, it may be reasonable to assume recovery has occurred, or is in progress, in less impacted areas. Although our 2009 estimate of abundance at Knight Island remains less than the estimate of pre-spill abundance (Dean and others, 2000), the highly significant increasing trend since 2003 results in an upper 95-percent confidence interval (79-153) for a population size in 2009 that is only slightly less than the pre-spill estimate of 165 animals. 


\section{Conclusions}

The endpoints for considering sea otter populations recovered from the Exxon Valdez oil spill include attainment of pre-spill sea otter abundance. Because accurate estimates of abundance prior to the spill are not available at most spatial scales, defining a single numerical recovery endpoint was not possible. Bodkin and others (2002) described the process toward recovery at the scale of western Prince William Sound (WPWS), as population estimates that were increasing significantly and that approximated the minimum mortality estimate of 750 animals. That trend in WPWS has continued, and in 2009, the estimate was approximately 2,000 animals more than the first post-spill estimate and about 650 animals less than the higher acute mortality estimate for Prince William Sound. We interpret this increase as continued progress toward recovery that eventually may best be defined by the population size as it reaches an asymptote. Since 2003, we have seen significant increases in sea otter abundance at northern Knight Island that we interpret as progress toward recovery. In this case, we would infer recovery when the current northern Knight population of 116 animals approximates the pre-spill population size estimated at 165 animals. If similar rates of increase continue, northern Knight Island may achieve prespill sea otter abundance within the next 2-3 years.

\section{References Cited}

Ballachey, B.E., Bodkin, J.L., and DeGange, A.R., 1994, An overview of sea otter studies, in Loughlin, T.R., ed., Marine mammals and the Exxon Valdez: Academic Press, San Diego, p. 47-59.

Ballachey, B.E., Bodkin, J.L., Howlin S., Doroff, A.M., and Rebar, A.H, 2003, Correlates to survival of juvenile sea otters in Prince William Sound, Alaska: Canadian Journal of Zoology, no. 81, p. 1494-1510.

Bodkin, J.L., Ballachey, B.E., Dean, T.A., Fukuyama, A.K., Jewett, S.C., McDonald, L., Monson, D.H., O’Clair, C.E., and Van Blaricom, G.R., 2002, Sea otter population status and the process of recovery from the 1989 'Exxon Valdez’ oil spill: Marine Ecology Progress Series, v. 241, p. 237-253.

Bodkin, J.L., and Udevitz, M.S., 1994, An intersection model for estimating sea otter mortality along the Kenai Peninsula, in Loughlin, T.R., ed., Marine mammals and the Exxon Valdez: Academic Press, San Diego, p. 81-95.
Bodkin, J.L., and Udevitz, M.S., 1999, An aerial survey method to estimate sea otter abundance, in Garner, G.W., Amstrup, S.C., Laake, J.L., Manly, B.J.F., McDonald, L.L., and Robertson, D.G., eds., Marine mammal survey and assessment methods: AA Balkema, Rotterdam, Netherlands, p. 13-26.

Burn, D.M., 1994, Boat-based population surveys of sea otters in Prince William Sound, in Loughlin, T.R., ed., Marine mammals and the Exxon Valdez: Academic Press, San Diego, p. 61-80.

Dean, T.A., Bodkin, J.L., Fukuyama, A.K., Jewett, S.C., Monson, D.H., O’Clair, C.E., and VanBlaricom, G.R., 2002, Food limitation and the recovery of sea otters following the Exxon Valdez oil spill: Marine Ecology Progress Series, v. 241, p. 255-270.

Dean, T.A., Bodkin, J.L., Jewett, S.C., Monson, D.H., and Jung D., 2000, Changes in sea urchins following a reduction in sea otter density as a result of the Exxon Valdez oil spill: Marine Ecology Progress Series, v. 199, p. 281-291.

Estes, J.A., Bodkin, J.L., and Ben-David, M., 2008, Marine otters, in Perrin, W.F., Wursig, B., Thewissen, J.G.M., and Crumly, C.R., eds., Encyclopedia of Marine Mammals (2d ed.): Academic Press, San Diego.

Exxon Valdez Oil Spill Trustee Council, 2006, Exxon Valdez Oil Spill Restoration Plan-Update on injured resources and services: Anchorage, Alaska, 41 p., accessed August 31, 2011, at http://www.evostc.state.ak.us/Universal/ Documents/Publications/2006IRSUpdate.pdf.

Garrott, R.A., Eberhardt, L.L., and Burn, D.M., 1993, Mortality of sea otters in Prince William Sound following the Exxon Valdez oil spill: Marine Mammal Science, v. 9, no. 4, p. 343-359.

Garshelis, D.L., 1997, Sea otter mortality estimated from carcasses collected after the Exxon Valdez oil spill: Conservation Biology, v. 11, no. 4, p. 905-916.

Monson, D.H., Doak, D.F., Ballachey, B.E., Johnson, A., and Bodkin, J.L., 2000, Long-term impacts of the Exxon Valdez oil spill on sea otters, assessed through age-dependent mortality patterns: Proceedings of the National Academy of Sciences, v. 97, p. 6562-6567.

Peterson, C.H., 2000, The Exxon Valdez oil spill in Alaskaacute, indirect, and chronic effects on the ecosystem: Advances in Marine Biology, v. 39, p. 1-103.

Peterson, C.H., Rice, S.D., Short, J.W., Esler, D. Bodkin, J.L., Ballachey, B.E., and Irons, D.B., 2003, Long-term ecosystem response to the Exxon Valdez oil spill: Science, v. 302, no. 5653, p. 2082-2086. 
Riedman, M.L., and Estes, J.A., 1990, The sea otter (Enhydra lutris)—Behavior, ecology, and natural history: U.S. Fish Wildlife Service Biological Report 90, no. 14, 125 p.

Short, J.W., Lindeberg, M.R., Harris, P.M., Maselko, J.M., Pela, J.J., and Rice, S.D., 2004, Estimate of oil persisting on the beaches of Prince William Sound 12 years after the Exxon Valdez oil spill: Environmental Science and Technology, v. 38, no. 1, p. 19-25.
Short, J.W., Maselko, J.M., Lindeberg, M.R., Harris, P.M., and Rice, S.D., 2006, Vertical distribution and probability of encountering intertidal Exxon Valdez oil on shorelines of three embayments within Prince William Sound, Alaska: Environmental Science and Technology, v. 40, p. 3723-3729.

Udevitz, M.S., Ballachey, B.E., and Bruden, D.L., 1996, A population model for sea otters in western Prince William Sound: Exxon Valdez Oil Spill Federal/State Restoration Project Final Report (Restoration Project 93043-3), National Biological Service, Anchorage, AK, 34 p. 
Publishing support provided by the U.S. Geological Survey Publishing Network, Tacoma Publishing Service Center

For more information concerning the research in this report, contact the Director, Alaska Science Center

U.S. Geological Survey

4210 University Dr.

Anchorage, Alaska 99508-4650

http://alaska.usgs.gov 


\section{总}

맘

⿳亠丷厂

高

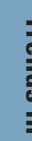

